\title{
The Form of Agreement on the Transfer of Rights and Obligations of a Party to a Contractual Relationship ${ }^{2}$
}

Submitted: 12.05.2020. Accepted: 25.03.2021

\begin{abstract}
This article seeks to explore the issue of the required form of agreement on the transfer of rights and obligations of a party to a contractual relationship by a third party, which in the Polish legal system functions as an innominate contract and is more common in foreign legislations (Vertragsübernahme, transfer of contract, cession de contract). This issue has been analysed taking into account the various possible configurations of parties to such an agreement as well as the various legal natures of the rights and obligations transferred. So far, this matter has not been thoroughly discussed in the Polish legal literature. According to the author, in line with the unity theory, an agreement on the transfer of rights and obligations of a party to a contractual relationship should be classified as a single legal transaction and not as two separate (independent) transactions of claim assignment (Article 509 of the Civil Code) and debt transfer (division theory). Therefore, it requires a written form otherwise being invalid. This requirement applicable to an entire agreement results from Article 522 sentence 1 of the Civil Code; it also meets less strict formal requirements regarding claim assignment (Article 511 of the Civil Code). In this paper, the author also discusses the question of whether Article $77 \S 1$ of the Civil Code and pactum de forma regarding amendments to an agreement (Article 76 sentence 1 of the Civil Code) apply to the form of the agreement in question.
\end{abstract}

Keywords: transfer of rights and obligations, form of legal transactions, assignment of rights, debt transfer.

1 PhD Przemysław Drapała - Professor of Kozminski University (Poland); e-mail: pdrapala@kozminski@ edu.pl; ORCID: 0000-0001-8093-2083.

2 The research project is not funded by any institution. 


\section{PRZEMYSŁAW DRAPAŁA}

\section{Forma umowy przeniesienia praw i obowiązków strony umowy ${ }^{3}$}

\section{Streszczenie}

Celem artykułu jest analiza problemu formy wymaganej dla umowy o przejęcie praw i obowiązków jednej ze stron stosunku obligacyjnego przez podmiot trzeci, uznawanej w naszym systemie prawnym za umowę nienazwaną, znanej szerzej w obcych ustawodawstwach (Vertragsübernahme, transfer of contract, cession de contract). Zagadnienie to rozważane jest $\mathrm{z}$ uwzględnieniem różnych możliwych konfiguracji podmiotowych tej umowy, a także różnej natury prawnej przejmowanych praw i obowiązków. Problem ten nie był dotąd przedmiotem pogłębionych rozważań w polskim piśmiennictwie. Zdaniem autora umowę przejęcia praw i obowiązków jednej ze stron stosunku zobowiązaniowego należy zgodnie z teorią jedności kwalifikować jako jednorodną czynność prawną, nie zaś jako złożenie dwóch odrębnych (samodzielnych) czynności cesji wierzytelności (art. 509 k.c.) i przejęcia długu (teoria podziału). Wymaga ona zatem dochowania formy pisemnej pod rygorem nieważności. Wymóg ten odnoszony do całej umowy wynika z art. 522 zd. 1 k.c., przy czym wyczerpuje zarazem łagodniejsze wymogi formalne przewidziane dla cesji wierzytelności (art. 511 k.c.). W artykule autor odnosi się również do zagadnienia, czy do formy analizowanej umowy znajduje zastosowanie art. 77 $\S 1$ k.c. oraz pactum de forma odnosząca się do czynności zmian treści umowy (art. 76 zd. 1 k.c.).

Słowa kluczowe: przeniesienie praw i obowiązków, forma czynności prawnej, cesja praw, cesja wierzytelności.

3 Projekt badawczy nie jest finansowany przez żadną instytucję. 


\section{The legal nature of an agreement on the transfer of rights and obligations of a party to a contractual relationship}

In the Polish literature and judicature in the field of civil law, a legal transaction leading to a transfer of rights and obligations of a party to a contractual relationship to a third party who becomes a party to that relationship in place of its predecessor has long been considered admissible. ${ }^{4}$ Such transaction is classified as contractus innominati, and according to the prevailing view, it is a claim transfer (Article 509 of the Civil Code) and a debt take-over (Article 519 of the Civil Code), ${ }^{5}$ and therefore should contain inherent elements of both of these legal concepts. ${ }^{6}$ In the foreign literature, an agreement leading to a transfer of rights and obligations of a party to a contractual relationship to a third party who as a result becomes a party of that relationship in place of its predecessor is defined as a "contract take-over" (Vertragsübernahme), "transfer of contract", "transfer of contractual position" or "contract assignment" (cession de contract). ${ }^{7}$ So far, no consistent terminology has been developed in the views of legal academics and commentators, as well as in the established

4 See E. Łętowska, [in:] System prawa cywilnego, Zobowiązania - część ogólna, Vol. III, part 1, Warszawa-Wrocław 1981, p. 899; W. Czachórski, Zobowiązania. Zarys wykładu, Warszawa 2002, p. 329; Z. Radwański, Zobowiązania. Część ogólna, Warszawa 2008, p. 363; K. Zawada, Umowa przelewu wierzytelności, Kraków 1990, p. 22. For more details see P. Drapała, Przejęcie dlugu, przejęcie praw i obowiązków z umowy (zmiana strony umowy), Warszawa 2016, p. 261 et seq.

5 Judgment of the Supreme Court of 17.05.2012, I CSK 315/11, unpublished; judgment of the Supreme Court of 26.09.2008, V CSK 105/08; judgment of the Supreme Court of 26.09.2008, V CSK 105/08, "Palestra" 2008, 11-12, p. 307; judgment of the Supreme Court of 6.11.1972, III CRN 266/72, OSNC 1973, No. 9, item 160 with commentaries by Z. Policzkiewicz-Zawadzka, OSPiKA 1973, 8, item 194, and by A. Kubas, PiP 1974, 11, p. 169 et seq. Cf. resolution of the Supreme Court of 21.10.1994, III CZP 133/94, OSNC 1995, No. 2, item 36.

6 See judgment of the Supreme Court of 6.11.1972, III CRN 266/72, OSNC 1973, No. 9, item 160; judgment of the Supreme Court of 17.07.1999, I CKN 44/98, of 23.03.2000, II CSK 863/98, OSNC 2000, No. 10, item 183, of 15.10.2004 r., II CK 62/04, of 23.11.2005, II CK 232/05, of 17.05.2012, I CSK 494/11, and of 18.04.2012, V CSK 133/11; judgment of the Supreme Court of 23.04.2019, IV CSK 33/18. Judgment of the Supreme Court of 17.05.2012, I CSK 494/11; judgment of the Supreme Court of 17.05.2012, I CSK 315/11.

7 For more details on a change of parties to an agreement in light of comparative law and on projects regarding unification of civil law in the EU see Ch. von Bar (ed.), Study Group on a European Civil Code and Research Group on EC Private Law Acquis Group, Munich 2008, p. 1103 et seq.; F. Mazza, [in:] S. Vogenauer (ed.), Commentary on the UNIDROIT Principles of International Commercial Contracts (PICC), New York 2015, p. 1046-1047; D. Klimke, Die Vertragsübernahme, Tübingen 2010, p. 45 et seq.; P. Drapała, op. cit., p. 265 et seq. 
line of judicial decisions in Poland. Sometimes it is defined, for instance, as a "contractual change of a party to the agreement" or a "collective transfer of rights and obligations of a party to the agreement".

Further considerations will focus on the required form of a transfer of rights and obligations of a party to an agreement, taking into account the various possible configurations of participants of such a transfer as well as the various legal natures of the rights and obligations being transferred. The issue in question has not been discussed thoroughly in the Polish legal literature so far.

\section{The essential requirements regarding the form of an agreement on the transfer of rights and obligations}

An agreement on the transfer of rights and obligations of a party to a contractual relationship may be take the form of a bilateral agreement between a party to a contractual relationship whose rights and obligations are to be transferred (current party to an agreement) and a third party taking over such rights and obligations (transferee), with consent of the other party to this particular contractual relationship (being a third-party consent within the meaning of Article 63 of the Civil Code), or the form of a trilateral agreement among the persons mentioned above. The starting point for such considerations should be a claim that in both configurations mentioned above, the agreement requires a written form in order to be valid. This results from the application of the provisions regarding the required form of a claim assignment in conjunction with the provisions regarding a releasing debt transfer. However, the question of whether said norms should be applied directly or per analogiam remains to be answered.

A debt transfer in the case of an agreement on the transfer of rights and obligations is governed by Article 522 sentence 1 of the Civil Code, which provides for a requirement of a written form ad solemnitatem. Considering that an agreement on the transfer of rights and obligations should be classified as a single legal transaction (unity theory), ${ }^{8}$ and not as two separate transactions of a debt assignment and debt take-over (division theory), the said requirement under Article 522 sentence 1 of the Civil Code should be applied to the entire agreement and not only to the part regarding the change of the debtor (transfer of obligations). In principle, compliance with this requirement is sufficient regardless of the form of the legal transaction giving rise to the debt and claim to be transferred (e.g. form of a notarial deed). A claim assignment is governed by Article 60 of the Civil Code,

8 For more details see: P. Drapała, op. cit., p. 275-276. 
and claims stated in writing by Article 511 of the Civil Code; the written form ad solemnitatem pursuant to Article 522 sentence 1 of the Civil Code fulfils the required form for an assignment at the same time. An agreement on the transfer of rights and obligations may be contained in a single document or may be concluded by exchanging documents, each containing a respective statement of intent and a signature of a given party (Article $78 \S 1$ of the Civil Code). ${ }^{9}$ The requirement of a written form ad solemnitatem is intended to protect in particular the transferee from taking over another person's obligations and rights from a contractual relationship too hastily. Additionally, concluding an agreement in a written form makes it easier to determine whether the real intention of the parties is to have a third party take over rights and obligations of a current party to the contractual relationship and replace that party in the contractual relationship..$^{10}$ Since the standard contained in Article 522 sentence 1 of the Civil Code is imperative, the parties may not adopt less strict requirements for the form of the transfer of rights of one of them to a third party in the principal agreement.

Consideration should be given to the form of consent to be given by the other party of the contractual relationship to the transfer of the counterparty's rights and obligations to a third party. This issue concerns the aforementioned bilateral agreement on the transfer of rights and obligations concluded with consent of the other party to the contractual relationship. It should be stressed that in the context of the transfer of obligations (Article $519 \S 2$ (2) of the Civil Code), the consent of the other party to the contractual relationship is a creditor's consent to a debt transfer. Accordingly, 522 sentence 2 of the Civil Code, which provides for the requirement of a written form, otherwise the act being invalid, applies to the consent mentioned above. ${ }^{11}$ The other party may also effectively give its consent in such a way that after conclusion of an agreement on the transfer of rights and obligations, this party brings action against the transferee and takes other steps to pursue a claim against the transferee. ${ }^{12}$ The other party may refuse to give its consent in any form (Article 60 of the Civil Code).

\footnotetext{
9 Cf. resolution of the Supreme Court of 17.10.1979, III CZP 68/79, OSN 1980, No. 4, item 67.

10 Cf. judgment of the Supreme Court of 8.02.2002, II CKN 1160/99, unpublished.

11 See judgment of the Administrative Court in Białystok of 22.02.2017, I ACa 834/16.

12 Cf. judgment of the Supreme Court of 11.09.1958, 3 CR 1168/57, OSN 1960, sentence 2, item 40; judgment of the Supreme Court of 6.11.1997, I CKN 295/97.
} 


\section{The form of an agreement on the transfer of rights and obligations vs pactum de forma}

It seems important, from both the theoretical and the practical perspective, to answer the question whether the commonly used pactum de forma reservation (Article 76 sentence 1 of the Civil Code) that any amendments to an agreement must be made in an agreed special form in order to be valid also applies to a transfer of contractual rights and obligations to a third party. This issue was the subject of deliberations of the Supreme Court in its judgment of 23 April 2019 (IV CSK 33/18), ${ }^{13}$ however, it should be stressed that this was only a secondary analysis as the main deliberations regarded the settlement of expenses made for a leased object. In the case in question, the parties agreed in the lease agreement that any amendments to that agreement must be made in writing to be valid. The Supreme Court, having interpreted that pacti de forma found that it should also apply to a transfer of rights and obligations under that agreement to a third party as (quote) "changes of the parties to the agreement also constitute an amendment to the agreement".

The Supreme Court's view understood generally, in broader terms (not only in the context of that particular dispute), should not be accepted for a couple of reasons. First, the pactum de forma reservation (Article 76 of the Civil Code) made by the parties that any amendments to the agreement must be made in an agreed special form in order to be valid does not refer to an assignment of claims under that agreement (Article 509 of the Civil Code) or a releasing transfer of debt (Article 519 of the Civil Code) under that agreement, and hence nor to a transfer of rights and obligations under that agreement to a third party, which is a combination of the two above. Such pactum refers only to actions taken between the current parties consisting in a subsequent amendment to a concluded agreement. This should be distinguished from situations when one of the parties uses a separate legal mechanism i.e. a claim assignment to transfer a single right or all rights arising from a given agreement to a third party (Article 509 of the Civil Code). In such a case, the form of this transaction should be determined on the basis of Article 511 of the Civil Code - not on the basis of the pactum mentioned above. Accordingly, a transfer of certain rights under an agreement to a third party (assignee) resulting from a claim assignment should not be confused with a subsequent amendment of an agreement made by the current parties to that agreement. Similarly, a distinction should be drawn between a subsequent amendment of an agreement and a releasing debt transfer to a third party. The form of this transaction is regulated by Article 521 of the Civil Code, not by pactum de forma in the wording analysed

13 Unpublished. 
above. An agreement on the releasing debt transfer, both in the configuration set out in Article $519 \S 2$ (1) of the Civil Code and in Article $519 \S 2$ (2) of the Civil Code, is based on the principle of maintaining the identity (including the contents) of the entire obligation. ${ }^{14}$ Second, it seems that the Supreme Court also did not consider the fact that pactum de forma in the wording mentioned above produces only inter partes effects, which means that it cannot determine the form of an agreement on the claim assignment which is a transaction between one of the parties and a third party (assignee) or the form of an agreement on a releasing debt transfer also concluded between one of the parties and a third party (transferee). According to the views of legal academics and commentators, as well as the established line of judicial decisions, pactum de forma is effective only with respect to future actions made between the parties to a given agreement. ${ }^{15}$ Provisions obliging a party to comply with an agreed special form for an assignment of a claim arising from a given agreement should be deemed admissible. Such a restriction regarding the form of an assignment arises from Article 509 of the Civil Code not from Article 76 of the Civil Code, and considering that it has only inter partes effect, it refers only to the form of the statement of intent of the party to an agreement (assignor) - not to the form of the statement of intent of a third party (assignee). There are no normative grounds for extending the scope of such provisions beyond the contractual relationship. ${ }^{16}$

\section{The form of an agreement on the transfer of rights and obligations vs. Article $77 \S 1$ of the Civil Code}

What calls for an analysis is also the relationship between Article $77 \S 1$ of the Civil Code and the form of a transfer of rights and obligations arising from an agreement. According to the provision mentioned above, an agreement may be supplemented or amended only in the form stipulated by the law or agreed by the parties for its execution. It provides for a principle of consistency of the form of the original

14 On the principle of maintaining the identity of an obligation in a claim assignment see K. Zawada, Umowa przelewu..., p. 157; idem, [in:] System prawa prywatnego, t. 6, Prawo zobowiązań - część ogólna, Warszawa 2014, p. 1335-1336; judgment of the Supreme Court of 6.10.2006, V CSK 147/06; judgment of the Supreme Court of 29.1.2002, V CKN 696/00. On said principle in debt transfer see E. Łętowska, op. cit., p. 930; judgment of the Supreme Court of 19.11.2004, II CK 129/04, OSP 2006, No. 2, item 19.

15 Instead of many authors, see: Z. Radwański, Teoria umów, Warszawa 1977, p. 100 and P. Machnikowski, Swoboda umów wedlug art. 353 (1) k.c. Konstrukcja prawna, Warszawa 2005, p. 143.

16 Therefore, the position presented in the judgment of the Supreme Court of 25.03.1969, III CRN 416/68, OSNCP 1970 No. 2, item 34, inspires a discussion. 
agreement and subsequent actions taken by the parties to modify it. This principle refers to a form sensu stricto, understood as a set of formal requirements for a statement of intent (such as a simple written form, the form of a notarial deed), as well as a form identified with sanctions for failure to comply with these requirements (ad eventum, ad solemnitatem, ad probationem).${ }^{17}$ In the context of this problem a question arises whether the term "amendment of the agreement" used by the legislator in Article $77 \S 1$ of the Civil Code also refers to a transfer of rights and obligations under an agreement to a third party. This question should be answered in the negative. In principle, an agreement on the transfer of rights and obligations of a party to a contractual relationship does not lead to a change of the contractual relationship's content. As a result of the collective transfer of rights and take-over of obligations, what changes is only a party to a contractual relationship (singular succession), while the identity (including the content) of the obligation remains unchanged, which is typical for an assignment of a claim and a translative change of a debtor. ${ }^{18}$ It is also stressed in foreign legal views and judgments that the analysed case concerns a succession in the entire legal position of a party to an agreement (entire contractual position, ${ }^{19}$ Stellung als Vertragspartei), ${ }^{20}$ and a legal succession is of a derivative and translative nature. Therefore, it should be concluded that, in principle, Article $77 \S 1$ of the Civil Code does not apply to situations when the rights and obligations arising from a contractual relationship are transferred through a claim assignment (Article 509 of the Civil Code) and a releasing debt transfer (Article 519 of the Civil Code), and at the same time, such a transfer of rights and obligations does not entail any subsequent change of the obligation's content. This is important in the case of a transfer of rights and obligations arising from an agreement concluded in the form of a notarial deed, in the form of a deed with an officially certified signature or in the form of a deed with a certified date. If the rights and obligations are transferred without their content being additionally changed, it is enough to comply with the form requirements set out in Article 511 of the Civil Code and Article 521 of the Civil Code (i.e. written form required for validity) and not a derivative form arising from Article $77 \S 1$ of the Civil Code. In practice, it happens that apart from the transfer of rights and obligations to a third party, parties also wish to modify the content of the contractual relationship,

17 See Z. Radwański, O zmianie przepisów Kodeksu cywilnego dotyczących pisemnej formy oświadczeń woli, "Monitor Prawniczy" 2003, sentence 9, p. 939; R. Strugała, [in:] E. Gniewek, P. Machnikowski (eds.), Kodeks cywilny. Komentarz, Warszawa 2019, commentary to Article 77 of the Civil Code, point II.1.

18 For more details see P. Drapała, op. cit., p. 297 (and literature quoted therein).

19 For more details see Ch. von Bar (ed.), op. cit., p. 1102.

20 See D. Klimke, op. cit., p. 245-246; Ch. Bauer, Parteiwechsel im Vertrag, Zürich 2010, p. 182-186. 
including in particular the (primary or secondary) rights and obligations. ${ }^{21}$ In such a situation, the form of the modifying action is the same as that stipulated by the law or agreed by the parties for the execution of the agreement.

\section{The form of the sequential transfer of rights and obligations}

As the Supreme Court stated in its judgments, the rights and obligations of a party to a contractual relationship may be transferred not only in a single legal transaction but also "gradually", ${ }^{22}$ which should be understood, for instance, as conclusion of separate agreements on claims assignment and on debt transfer. This suggests an analogy to a sequential acquisition of an enterprise (Article $55^{4}$ of the Civil Code $)^{23}$ as a consequence of several legal transactions. Basing on the principle of unity of an agreement on the transfer of rights and obligations it should be concluded that In order to determine the form, in such a case, it will be decisive to determine whether the joint purpose of the parties to the contracts concluded successively was to transfer to a third party the rights and obligations of one of the parties to the contractual relationship, and, consequently, to enter into the entire legal situation of that party. The aforementioned requirement of a written form for validity (Article 522 sentence 1 of the Civil Code) should be fulfilled with respect to all agreements which collectively lead to a change of a party to a contractual relationship.

\section{The form of an agreement on the transfer of rights regarding a mortgage-secured claim}

The transfer of rights and obligations of a party to an agreement involving a transfer of a mortgage-secured claim requires a separate analysis. Such a transfer does not require a special form. Given that a constitutive entry in a land and mortgage register is required for this type of transfer (Article 79(1) sentence 2 of the Act on Land and Mortgage Registers and Mortgage), the assignor's statement of intent should be made in an ad intabulationem written form with a notarised signature

21 Cf. V. Rieble, [in:] Staudingers Kommentar zum Bürgerlichen Gesetzbuch mit Einführungsgesetz und Nebengesetzen, Vol. II [\$\$397-424], Berlin 2012, p. 323.

22 See judgment of the Supreme Court of 17.05.2012, I CSK 494/11, unpublished.

23 See judgment of the Supreme Court of 6.07.2005, III CK 705/04, unpublished. 
(Article 31 (1) of said act). This is an ad eventum form, ${ }^{24}$ and failure to comply with it results in the dismissal of the application for entry of the claim's acquirer into a land and mortgage register (Article $626^{9}$ of the Code of Civil Procedure). To transfer a mortgage-secured claim arising from a bank transaction, it is enough that the bank (assignor) makes a statement in the form stipulated in Article 95(1) and (6) of the Banking Act, whereas the assignee may make the statement of intent in a written, documentary or electronic form with an ad probationem effect. ${ }^{25} \mathrm{~A}$ transfer of such a claim, if mortgage is established by a third party, does not require consent of this third party unless an agreement on establishing a mortgage so requires. ${ }^{26} \mathrm{~A}$ dispositive effect of the transfer of a mortgage-secured claim depends on the entry in a land and mortgage register, ${ }^{27}$ and has retroactive force from the filing of the application (Article 29 of the Act on Land and Mortgage Registers and Mortgage). The view that Article 79 (1) of the Act on Land and Mortgage Registers and Mortgage should not be applied per analogiam to a mortgage-secured debt transfer is correct. ${ }^{28}$ So is the hypothesis of the standard mentioned above as its ratio legis refers only to a change of the creditor.

\section{Conclusions}

Considering that pursuant to the unity theory, an agreement on the transfer of rights and obligations of a party to a contractual relationship should be classified as a single legal transaction and not as two separate (independent) transactions of a claim assignment (Article 509 of the Civil Code) and a debt transfer (division theory), such an agreement requires a written form in order to be valid. The requirement arises from Article 522 sentence 1 of the Civil Code and should be applied to the entire agreement; it also meets less strict formal requirements stipulated for a claim assignment (Article 511 of the Civil Code). In terms of the form, it is irrelevant whether the agreement is concluded as a bilateral or trilateral agreement or whether the rights and obligations are transferred sequentially (gradually). In principle, as a result of the agreement in question, the content of a contractual

24 See decision of the Supreme Court of 17.11.2011, IV CSK 74/11, unpublished.

25 Cf. J. Pisuliński, [in:] System Prawa Prywatnego. Prawo rzeczowe, Vol. 4, Warszawa 2012, p. 604.

26 See decision of the Supreme Court of 16.03.2018, IV CSK 280/17, unpublished.

27 See judgment of the Supreme Court of 12.09.2019, V CSK 267/18, unpublished; decision of the Supreme Court of 13.5.2010, IV CSK 469/09, unpublished; decision of the Supreme Court of 13.5.2010, IV CSK 486/09, unpublished.

28 See A. Tułodziecka, [in:] I. Heropolitańska, A. Tułodziecka, K. Hryćków-Mycka (eds.), Ustawa o księgach wieczystych i hipotece. Komentarz, Warszawa 2019, commentary to Article 79, point D.1. 
relationship does not change - the only change is that a transferee takes over (singular succession) the rights and obligations of a current party to the agreement, and the identity of the current obligation remains unchanged. Consequently, Article $77 \S 1$ of the Civil Code or pacti de forma regarding amendment of an agreement's content (Article 76 sentence 1 of the Civil Code) does not apply to such an agreement.

\section{Bibliography}

Bar Ch., von (ed.), Study Group on a European Civil Code and Research Group on EC Private Law Acquis Group, Munich 2008.

Bauer Ch., Parteiwechsel im Vertrag, Zürich 2010.

Czachórski W., Zobowiqzania. Zarys wykładu, Warszawa 2002.

Drapała P., Przejęcie dlugu, przejęcie praw i obowiązów z umowy (zmiana strony umowy), Warszawa 2016.

Klimke D., Die Vertragsübernahme, Tübingen 2010.

Łętowska E., [in:] System prawa cywilnego, Zobowiązania - część ogólna, Vol. III, part 1, Warszawa-Wrocław 1981.

Machnikowski P., Swoboda umów wedtug art. 353 (1) k.c. Konstrukcja prawna, Warszawa 2005.

Mazza F., [in:] S. Vogenauer (ed.), Commentary on the UNIDROIT Principles of International Commercial Contracts (PICC), New York 2015.

Pisuliński J. [in:] System Prawa Prywatnego. Prawo rzeczowe, Vol. 4, Warszawa 2012.

Radwański Z., Zobowiq̨zania. Część ogólna, Warszawa 2008.

Radwański Z., O zmianie przepisów Kodeksu cywilnego dotyczacych pisemnej formy oświadczeń woli, "Monitor Prawniczy" 2003, sentence 9.

Radwański Z., Teoria umów, Warszawa 1977.

Rieble V., [in:] Staudingers Kommentar zum Bürgerlichen Gesetzbuch mit Einführungsgesetz und Nebengesetzen, Vol. II [\$§397-424], Berlin 2012.

Strugała R., [in:] E. Gniewek, P. Machnikowski (eds.), Kodeks cywilny. Komentarz, Warszawa 2019.

Tułodziecka A., [in:] I. Heropolitańska, A. Tułodziecka, K. Hryćków-Mycka (eds.), Ustawa o ksieggach wieczystych i hipotece. Komentarz, Warszawa 2019.

Zawada K., [in:] System prawa prywatnego, t. 6, Prawo zobowiazań - część ogólna, Warszawa 2014.

Zawada K., Umowa przelewu wierzytelności, Kraków 1990. 